\title{
KAJIAN PRESTASI BELAJAR BIOLOGI MENGGUNAKAN MODEL SETS (SCIENCE, ENVIRONMENT, TECHNOLOGY, AND SOCIETY) DENGAN METODE OBSERVASI LABORATORIUM DAN METODE OBSERVASI LAPANGAN DI TINJAU DARI SIKAPILMIAH DAN KREATIVITAS SISWA
}

\author{
Joko Dwi Suranto ${ }^{1}$, Sajidan ${ }^{2}$ dan Suciati $^{3}$ \\ ${ }^{1}$ Program Studi Magister Pendidikan Sains FKIP Universitas Sebelas Maret \\ Surakarta, 57126, Indonesia \\ juldafaza@yahoo.co.id \\ ${ }^{2}$ Program Studi Magister Pendidikan Sains FKIP Universitas Sebelas Maret \\ Surakarta, 57126, Indonesia \\ sajidan_fkip@staff.uns.ac.id \\ ${ }^{3}$ Program Studi Magister Pendidikan Sains FKIP Universitas Sebelas Maret \\ Surakarta, 57126, Indonesia \\ suciati.sudarisman@yahoo.com
}

\begin{abstract}
Abstrak
Penelitian ini bertujuan untuk mengetahui pengaruh pembelajaran model SETS (Science, Environment, Technology, and Society) dengan metode observasi laboratorium dan metode observasi lapangan, sikap ilmiah dan kreativitas siswa serta interaksi ketiganya terhadap prestasi belajar siswa. Penelitian ini menggunakan metode eksperimen dan dilaksanakan Oktober 2011 sampai bulan Juni 2012. Populasi semua siswa kelas VII SMPN 2 Jatiroto, Wonogiri. Sampel penelitian diambil dengan metode cluster random sampling terdiri dari 2 kelas. Kelas VII A menggunakan model SETS dengan metode observasi laboratorium dan kelas VII B menggunakan model SETS dengan metode observasi lapangan. Data sikap ilmiah siswa dan kreativitas siswa sebagai variabel moderator diperoleh melalui angket, data prestasi belajar sebagai variabel terikat untuk aspek kognitif diperoleh melalui tes, dan data prestasi aspek afektif dan aspek psikomotor melalui lembar observasi. Analisis data menggunakan uji Anava desain faktorial 2x2x2 menggunakan software komputer SPSS 17. Hasil penelitian menunjukkan: (1) ada pengaruh prestasi belajar antara siswa yang diberi pembelajaran biologi model SETS dengan metode observasi laboratorium dan metode observasi lapangan; (2) ada pengaruh sikap ilmiah tinggi dan sikap ilmiah rendah terhadap prestasi belajar siswa; (3) ada pengaruh antara kreativitas tinggi dan kreativitas rendah terhadap prestasi belajar siswa; (4) tidak terdapat interaksi antara model SETS dengan metode observasi laboratorium dan metode observasi lapangan dengan sikap ilmiah terhadap prestasi belajar siswa; (5) tidak terdapat interaksi antara model SETS dengan metode observasi laboratorium dan metode observasi lapangan dengan kreativitas terhadap prestasi belajar siswa; (6) tidak terdapat interaksi antara sikap ilmiah dan kreativitas terhadap prestasi belajar siswa; (7) tidak terdapat interaksi antara metode observasi laboratorium dengan metode observasi lapangan, sikap ilmiah dan kreativitas terhadap prestasi belajar siswa.
\end{abstract}

Kata Kunci: model SETS, metode observasi, prestasi belajar

\section{Pendahuluan}

Pendidikan IPA di sekolah diharapkan dapat menjadi wahana bagi peserta didik untuk mempelajari diri sendiri dan alam sekitar, serta prospek pengembangan lebih lanjut dalam menerapkannya untuk memecahkan berbagai permasalahan kehidupan seharihari yang didasarkan pada metode ilmiah. Pembelajaran IPA seharusnya menekankan pada pengalaman langsung untuk 
mengembangkan kompetensi agar peserta didik mampu menahami alam sekitar melalui proses "mencari tahu" dan "berbuat", hal ini akan membantu peserta didik untuk memperoleh pemahaman yang lebih mendalam (Hakim, 2008).

Menurut Carin dan Sund dalam Wenno (2008: 3) menyatakan bahwa sains adalah scientific processes atau scientific methods adalah cara khusus dalam penyelidikan untuk memecahkan suatu masalah, misalnya membuat hipotesis, merancang dan melaksanakan eksperimen, mengumpulkan dan menyusun data, mengevaluasi data, mengukur dan sebagainya. Scientific products (produk ilmiah) adalah berupa fakta, prinsip, hukum, teori dan lain-lain, misalnya prinsip ilmiah. Scientific attitudes adalah keyakinan, nilai-nilai, pendapat/gagasan dan objektif, misalnya keputusan setelah memperoleh data yang berkaitan dengan permasalahan selalu berusaha bersikap objektif dan jujur (Wenno, 2008)

Kondisi proses pembelajaran IPA di SMP Negeri 2 Jatiroto, Wonogiri, Jawa Tengah, berdasarkan observasi proses pembelajaran pada mata pelajaran IPA, menunjukkan bahwa pembelajaran belum diajarkan sesuai dengan hakikat IPA. Kecenderungan pembelajaran IPA di sekolah khususnya di SMP Negeri 2 Jatiroto, Wonogiri, Jawa Tengah, berlangsung dengan pendekatan behaviorisme yang dalam implementasinya berupa ceramah.

Pembelajaran oleh guru tidak membuat tantangan intelektual siswa, akibatnya kemampuan siswa memecahkan masalah rendah. Pembelajaran tidak kontekstual dan suasana pembelajaran tidak menyenangkan bagi siswa, karena tidak adanya kesempatan bagi siswa untuk belajar sesuai dengan keinginannya, akibatnya prestasi belajar siswa rendah. Hanya 50\% siswa memperhatikan guru dalam menerangkan materi..

Dampak lain dari munculnya teacher centered antara lain sikap ilmiah siswa sebagai faktor internal tidak dipertimbangkan sebagai salah satu faktor pencapaian prestasi belajar. Proses pembelajaran yang tidak melibatkan siswa untuk mengembangkan sikap-sikap untuk mengemukakan gagasan dan menghargai gagasan orang lain, terbuka terhadap gagasan baru, berpikir kritis, jujur, kerjasama dan kreatif menjadikan prestasi belajar menjadi tidak optimal.

Pembelajaran yang terpusat pada guru juga menyebabkan siswa kurang terdorong kreativitasnya, sehingga pembelajaran menjadi menjemukan. Siswa juga tidak mendapatkan kesempatan untuk berpikir kritis, analisis, sistematis, dan logis, untuk menemukan alternatif pemecahan masalah yang berkaitan dengan kehidupan sehari-hari. Menurut Sardiman (2001:3) kreativitas siswa sebagai faktor internal siswa dalam pembelajaran yang berpengaruh terhadap pretasi belajar. Kreativitas kurang dipertimbangkan guru dalam proses pembelajaran, sehingga prestasi belajar IPA menjadi tidak bisa optimal. Guru sudah melakukan berbagai macam cara, seperti memberi kesempatan siswa untuk bertanya dan mengemukakan gagasan.

Data kurikulum sekolah diperoleh nilai rata-rata IPA masih rendah sekitar 65\% siswa memperoleh nilai di bawah nilai KKM (Kriteria Ketuntasan Minimal) yaitu 70. Masih rendahnya nilai IPA, karena guru belum melaksanakan pembelajaran dengan metode yang tepat. Guru belum optimal dalam menggunakan fasilitas yang ada di sekolah. Padahal fasilitas sekolah yang berupa laboratorium biologi dengan peralatan biologi dan bahan-bahan praktikum tersedia dalam laboratorium. Penggunaan laboratorium sekolah baru dilakukan oleh $40 \%$ guru IPA. Sementara fasilitas sekolah yang berupa lingkungan yang luas dengan penghijauan dan tanamisasi juga merupakan laboratorium alam yang dapat digunakan sebagai sarana pembelajaran baru sekitar $40 \%$ yang memanfatkan sebagai sumber belajar.

Model pembelajaran SETS (Science, Environment, Technology, and Society) 
merupakan salah satu model untuk menyesuaikan diri terhadap perkembangan sains yang cepat dan menjawab perubahan paradigma baru dalam pembelajaran. Model ini menfasilitasi pembelajaran yang menyangkut permasalahan lingkungan. Pembelajaran biologi bervisi SETS mengatasi kelemahan sistem pendidikan konvensional yang mendorong siswa memahami teori "materi oriented" dan menyelesaikan materi pelajaran, tanpa tahu masalah-masalah di masyarakat baik secara lokal, nasional, maupun internasional.

Sasaran pembelajaran dengan model SETS adalah cara membuat siswa dapat melakukan penyelidikan untuk mendapatkan pengetahuan yang berkaitan dengan sains, lingkungan, teknologi dan masyarakat. Siswa dibawa pada suasana yang dekat dengan kehidupan nyata siswa sehingga siswa dapat mengembangkan pengetahuan yang telah dimiliki siswa untuk dapat menyelesaikan masalahmasalah yang diperkirakan akan timbul di sekitar kehidupannya. Konteks SETS dalam pembelajaran biologi, memerlukan kesediaan guru atau pendidik untuk memiliki cara pandang terbuka di samping aktif mengikuti perkembangan yang terjadi di dalam masyarakat berkenaan dengan subjek biologi. Diperlukan kepekaan yang tinggi dari guru biologi sangat diperlukan terhadap situasi di masyarakat yang bernuansa biologi.

SETS atau yang sering disebut Salingtemas (sains, lingkungan, teknologi dan masyarakat) merupakan kecenderungan masa depan pendidikan yang belum banyak disadari oleh masyarakat (Binadja, 2001). Oleh karena itu salah satu usaha untuk membumikan SETS dalam kehidupan mungkin bisa diawali melalui pendidikan formal di sekolah dimana materi-materi pelajaran disampaikan oleh guru selalu dihubungkaitkan dengan SETS. Pengertian tersebut hampir sama dengan yang dinyatakan dalam Depdiknas (2002:5) bahwa dengan pendekatan Salingtemas/SETS siswa dikondisikan agar mau dan mampu menerapkan prinsip sains untuk menghasilkan karya teknologi diikuti dengan pemikiran untuk mengurangi atau mencegah kemungkinan dampak negatif yang mungkin timbul dari munculnya produk teknologi ini terhadap lingkungan dan masyarakat.

Pembelajaran kontekstual dengan model SETS dengan metode observasi laboratorium dan metode observasi lapangan meningkatkan prestasi belajar siswa, selain penggunaan model dan metode yang tepat, guru perlu mempertimbangkan sikap ilmiah dan kreativitas siswa. Sikap ilmiah siswa dipilih karena dalam model pembelajaran SETS tidak hanya meningkatkan kemampuan kognitif, namun juga dikembangkan keterampilan emosional, spiritual dan kemampuan kreatif siswa. Aspek afektif yakni sikap dalam bentuk kepedulian terhadap lingkungan dan kepedulian terhadap teman juga dikembangkan. (Wasis, 2008).

\section{Metode Penelitian}

Pelaksanaan penelitian di SMP Negeri 2 Jatiroto, Wonogiri, Jawa Tengah. Objek penelitian diambil kelas VII semester 2 (genap) Tahun Pelajaran 2011/2012. Metode yang digunakan adalah metode eksperimen dengan desain faktorial $2 \times 2 \times 2$ yang melibatkan dua kelompok eksperimen tanpa melibatkan kelompok kontrol. Kelompok eksperimen pertama diberi metode observasi laboratorium dan kelompok eksperimen kedua diberi metode observasi lapangan.

Teknik sampling yang digunakan adalah teknik "cluster random sampling" yaitu pengambilan sampel dengan memperhatikan unsur kelas atau kelompok yang terdapat dalam populasi (Suharsimi, 2006). Instrumen pengambilan data dalam penelitian berupa data tes prestasi belajar kognitif, lembar penilaian afektif dan lembar observasi psikomotor, serta angket untuk sikap ilmiah dan kreativitas siswa.

Uji normalitas dalam penelitian ini menggunakan uji Shapiro-Wilk Test. Uji 
homogenitas menggunakan uji Lavene's. Analisis data menggunakan statistik Anava 3 jalan sel tidak sama dengan taraf signifikansi $\alpha=0.05$. Uji hipotesis dilakukan dengan Test of Between Effects. Uji lanjut dengan Uji Scheffe dengan bantuan komputerisasi sistem SPSS 17 (Budiyono, 2004).

\section{Hasil Penelitian dan Pembahasan}

Rangkuman hasil uji Anava tiga jalan dengan taraf signifikansi $\alpha=0.05$ terhadap prestasi belajar siswa disajikan pada Tabel 1.

Tabel 1. Rangkuman Hasil Uji Anava Tiga Jalan Terhadap Prestasi Belajar Kognitif, Afektif dan Psikomotor

\begin{tabular}{|c|c|c|c|c|}
\hline \multirow{2}{*}{ No. } & \multirow{2}{*}{ Aspek } & \multicolumn{3}{|c|}{ p-value Prestasi Belajar } \\
\hline & & Kognitif & Afektif & Psikomotor \\
\hline 1 & $\begin{array}{l}\text { Metode } \\
\text { Observasi }\end{array}$ & 0.009 & 0.022 & 0.024 \\
\hline 2 & Sikap Ilmiah & 0.000 & 0.002 & 0.002 \\
\hline 3 & Kreativitas & 0.036 & 0.017 & 0.019 \\
\hline 4 & $\begin{array}{l}\text { Interaksi antara } \\
\text { Metode dengan } \\
\text { Sikap Ilmiah }\end{array}$ & 0.080 & 0.309 & 0.276 \\
\hline 5 & $\begin{array}{l}\text { Interaksi antara } \\
\text { Metode dengan } \\
\text { Kreativitas }\end{array}$ & 0.982 & 0.275 & 0.282 \\
\hline 6 & $\begin{array}{l}\text { Interaksi antara } \\
\text { Sikap Ilmiah } \\
\text { dengan } \\
\text { Kreativitas }\end{array}$ & 0.159 & 0.384 & 0.386 \\
\hline 7 & $\begin{array}{l}\text { Interaksi antara } \\
\text { Metode, } \\
\text { Kreativitas dan } \\
\text { Sikap Ilmiah }\end{array}$ & 0.242 & 0.697 & 0.723 \\
\hline
\end{tabular}

Berdasarkan Tabel 1, hasil uji hipotesis menunjukkan bahwa $\mathrm{H}_{0 \mathrm{~A}}, \mathrm{H}_{0 \mathrm{~B}}, \mathrm{H}_{0 \mathrm{C}}$ masing-masing mempunyai $p$-value lebih kecil dari taraf signifikansi $(\alpha=0.05)$ jadi $\mathrm{H}_{\mathrm{o}}$ ditolak, $\mathrm{H}_{1}$ diterima berarti ada perbedaan yang signifikan antara prestasi belajar kognitif, afektif dan psikomotor antara siswa yang menggunakan model pembelajaran SETS dengan metode observasi laboratorium dan metode observasi lapangan. Metode observasi dengan model pembelajaran SETS berpengaruh terhadap prestasi belajar aspek kognitif, afektif dan psikomotor, sejalan dengan penelitian yang dilakukan oleh Del Rosario (2009) bahwa SETS merupakan sebuah model pembelajaran yang sangat cocok untuk materi-materi yang berhubungan dengan lingkungan.

Menurut Brunner dalam Arsyad (2005:7) bahwa dengan model pembelajaran SETS dengan metode laboratorium dan metode obsevasi lapangan, siswa akan memperoleh pengalaman baru dalam pemecahan masalah, mentranformasikan prestasi belajar dan menggunakan hasil penemuannya sehingga siswa dapat menemukan konsep dan hasil akhirnya akan diperoleh peningkatan prestasi belajar yang lebih baik. Pada sintaks SETS tahap eksplorasi, siswa akan memperoleh pengalaman langsung melalui pengamatan dan praktikum di laboratorium dan lapangan. Hal ini sesuai dengan tingkatan utama belajar yaitu pada tingkatan pengalaman langsung (enactitive). Pada tingkatan ketiga yaitu abstrak (symbolic), siswa mampu menyusun hipotesis dari praktikum yang dilakukan (Del Rosario. 2009).

Relevansi dengan teori Piaget bahwa model pembelajaran SETS dengan metode observasi laboratorium dan observasi lapangan dimana model pembelajaran ini diterapkan pada siswa SMP yang berusia 11 tahun - dewasa, sehingga sesuai berada dalam tahap perkembangan operasional formal dimana pada tahap ini siswa sudah dapat berpikir logis dalam memecahkan masalah, berpikir dengan pemikiran teoritis formal berdasarkan hipotesis-hipotesis dan dapat mengambil kesimpulan tentang apa yang diamatinya sebagaimana sintaks dalam model pembelajaran SETS.

Hasil uji Anava untuk prestasi belajar aspek kognitif, afektif dan psikomotor untuk hipotesis ini menunjukkan bahwa rata-rata nilai prestasi belajar kognitif, afektif dan psikomotor antara siswa yang menggunakan model pembelajaran SETS dengan metode observasi laboratorium lebih tinggi dibandingkan dengan kelas dengan metode observasi lapangan. Melalui model pembelajaran SETS dengan metode observasi laboratorium dalam proses penemuan konsep, siswa diberi bimbingan 
dan petunjuk yang jelas untuk mengidentifikasi penyebab pengelolaan lingkungan, yang pada akhirnya dapat menduga dampak sekaligus upaya pengelolaan lingkungan. Bimbingan dari guru akan menyebabkan pembelajaran menjadi terarah dalam penemuan konsep sehingga akan terjadi peningkatan prestasi belajar. Sementara pada model pembelajaran SETS dengan metode observasi lapangan dalam penemuan konsep, siswa akan mengobservasi kondisi lingkungan dan akan mencatat hasil observasi dengan menggunakan LKS yang telah disusun oleh guru. Metode observasi lapangan siswa hanya sekedar memperhatikan dan menyajikan bahan yang lebih konkret, tetapi hal ini masih sulit dilakukan oleh siswa kelas VII yang belum terlatih melaksanakan pembelajaran mandiri. Pembelajaran dengan model SETS dengan metode observasi laboratorium ini sangat membantu siswa dalam memecahkaan permasalahan kehidupan sehari-hari yang berkaitan dengan pengelolaan lingkungan.

Sejalan dengan penelitian Riyadi (2009) model pembelajaran SETS dengan metode eksperimen lebih berpengaruh terhadap prestasi belajar. Kondisi laboratorium akan membuat siswa lebih terfokus untuk mengobservasi dan menerima serta memecahkan permasalahan yang disajikan melalui tayangan masalah. Pembelajaran biologi pada materi pengelolaan lingkungan lebih efektif dan efisien diajarkan menggunakan pembelajaran dengan metode observasi laboratorium.

Ada pengaruh antara sikap ilmiah tinggi dan sikap ilmiah rendah terhadap prestasi belajar biologi aspek kognitif, afektif dan psikomotor. Pada dasarnya sikap ilmiah adalah suatu kecenderungan atau dorongan untuk berperilaku dan mengambil tindakan maupun pemikiran ilmiah sesuai dengan metode ilmiah. Mata pelajaran biologi merupakan salah satu cabang Ilmu Pengetahuan Alam yang mempelajari tentang fenomena-fenomena alam bertujuan agar siswa mampu menguasai konsepkonsep biologi dan saling berkaitannya serta mampu menggunakan metode ilmiah yang dilandasi sikap ilmiah untuk memecahkan masalah yang dihadapinya.

Penelitian yang dilakukan oleh Sayekti (2012) menyatakan bahwa ada pengaruh sikap ilmiah kategori tinggi dan rendah terhadap prestasi belajar IPA siswa. Hal ini karena ketiga aspek prestasi belajar baik aspek kognitif, afektif dan psikomotor dengan sikap ilmiah tersebut saling berhubungan satu sama lain. Berdasarkan penelitian tersebut, bahwa siswa yang memiliki sikap ilmiah tinggi dan rendah akan memberikan pengaruh yang berbeda terhadap prestasi belajar yang akan diperoleh. Sehingga diperlukan sikap ilmiah dari dalam diri siswa agar mampu memecahkan masalah yang dihadapinya. Sikap ilmiah sebagai faktor endogen patut dipertimbangkan dalam peningkatan prestasi belajar siswa.

Figuerido (2016) menyatakan bahwa melalui pendekatan STSE, pengetahuan dibangun ke dalam pengajaran dan pembelajaran membuat peserta aktif dalam masyarakat, atau lebih tepatnya kesadaran warga kritis, bertindak dan berinteraksi dalam masyarakat dan di lingkungan. Sejalan dengan penelitian ini bahwa sikap kritis yang terbentuk akan mempengaruhi prestasi belajar untuk ketiga aspek.

Ada pengaruh antara kreativitas tinggi dan kreativitas rendah terhadap prestasi belajar biologi aspek kognitif, afektif dan psikomotor. Siswa dengan kreativitas siswa tinggi memiliki rata-rata prestasi belajar aspek kognitif, afrktif dan psikomotor yang lebih baik. Kreativitas melibatkan belajar memecahkan masalah dan memerlukan banyak latihan dengan berbagai macam tipe masalah serta membutuhkan pemikiran yang kritis, realitas yang bersifat spontan atau improfisasi. Semakin banyak masalah yang dipelajari siswa untuk dipecahkan maka semakin banyak siswa tersebut berpikir sehingga kemampuan kognitifnya semakin meningkat. 
Sejalan dengan teori belajar Ausubel, bahwa kreativitas adalah kemampuan atau kapasitas pemahaman, sensitivitas, dan apresiasi dalam menyelesaikan suatu permasalahan. Sehingga selama dalam proses pembelajaran materi pengelolaan lingkungan, siswa dengan kreativitas tinggi memiliki bekal keterampilan yang lebih untuk memecahkan permasalahan yang berkaitan dengan pengelolaan lingkungan yang sering dijumpai dalam kehidupan sehari-hari sehingga akan terjadi peningkatan prestasi belajar.

Pada penelitian Setiyono (2011) bahwa kreativitas siswa dapat dibangun dengan pendekatan SETS. Pendekatan SETS, menuntut kreativitas dan keterampilan siswa dalam mengaitkan antara sains, lingkungan, teknologi dan masyarakat dalam proses menemukan konsep. Kreativitas merupakan dasar dari belajar, artinya jika siswa memiliki kreativitas tinggi maka ia akan memiliki keterampilaan dalam memecahkan permasalahaan yang mereka hadapi. Sebaliknya kreativitas rendah menjadikan semangat untuk belajar, menyelidiki, memecahkan masalah, dan hasrat untuk mengetahui juga rendah. Siswa tersebut tidak memiliki kemauan yang kuat untuk memecahkan suatu masalah.

Menurut Angel (2015) pendekatan SETS akan memberdayakan kerja mandiri dan penggunaan teknologi yang nyata di masyarakat. Pada dasarnya kreativitas siswa mendorong siswa untuk dapat bekerja mandiri dengan menggunakan teknologi yang ada untuk menyelidiki sesuatu dan menumbuhkan kemauan untuk belajar yang pada akhirnya memiliki prestasi yang lebih baik.

Sedangkan pada $\mathrm{H}_{0 \mathrm{AB}}, \mathrm{H}_{0 \mathrm{AC}}, \mathrm{H}_{0 \mathrm{BC}}$, $\mathrm{H}_{0 \mathrm{ABC}}$ masing-masing mempunyai $p$-value lebih besar dari taraf signifikansi $(\alpha=0,05)$ jadi $\mathrm{H}_{\mathrm{o}}$ diterima, $\mathrm{H}_{1}$ ditolak dan berarti tidak ada interaksi antara model pembelajaran SETS dengan metode observasi laboratorium dan metode observasi lapangan dengan sikap ilmiah siswa. Siswa yang mempunyai sikap ilmiah tinggi mempunyai kecenderungan untuk bertindak atau berperilaku dalam memecahkan masalah yang berkaitan dengan pengelolaan lingkungan melalui serangkaian kegiatan secara terstruktur dan sistematis melalui langkah-langkah ilmiah.

Maryati (2009) menyatakan bahwa sikap ilmiah tinggi dan sikap ilmiah rendah dalam model pembelajaran SETS mempengaruhi prestasi belajar siswa. Pada penelitian ini meskipun secara umum sikap ilmiah mempengaruhi prestasi belajar siswa tetapi interaksi keduanya dengan metode observasi dan observasi lapangan tidak menunjukkan interaksi antara keduanya. Hal ini dikarenakan baik pada metode observasi laboratorium maupun metode observasi lapangan, sikap ilmiah kategori tinggi memiliki prestasi belajar tinggi, sedangkan sikap ilmiah rendah baik pada metode observasi laboratorium maupun metode observasi lapangan memiliki prestasi belajar yang rendah. Sehingga antara model pembelajaran SETS dengan metode observasi laboratorium dan metode observasi lapangan tidak ada interaksi dengan sikap ilmiah kategori tinggi maupun rendah. Tidak adanya interaksi antara metode dan sikap ilmiah tinggi dan sikap ilmiah rendah terhadap prestasi belajar dimungkinkan karena pembelajaran terjadi pada jam-jam siang hari sehingga menyebabkan siswa malas berpikir secara ilmiah dalam memecahkan masalah yang dihadapinya.

Tidak ada interaksi antara pembelajaran dengan metode observasi laboratorium dan metode observasi lapangan dengan kreativitas siswa terhadap prestasi belajar. Model pembelajaran SETS baik dengan metode observasi laboratorium maupun metode observasi lapangan dan kreativitas siswa tidak saling mempengaruhi prestasi belajar secara bersama-sama. Model pembelajaran SETS baik dengan metode observasi laboratorium maupun metode observasi lapangan jika diterapkan pada siswa dengan kreativitas siswa tinggi, maka prestasi yang dihasilkan tetap tinggi. Sementara itu, model 
pembelajaran SETS baik metode observasi laboratorium maupun metode observasi lapangan jika diterapkan pada siswa dengan kreativitas siswa rendah, maka prestasi yang dihasilkan tetap rendah.

Model pembelajaran SETS menurut Binadja (2001) mempunyai karakteristik murid diminta untuk menjelaskan keterhubungkaitan antara unsur sains biologi yang dibincangkan dengan unsurunsur lain dalam SETS yang mempengaruhi berbagai keterkaitan antar unsur tersebut selain itu murid juga diajak untuk mempertimbangkan manfaat atau kerugian menggunakan konsep sains biologi tersebut bila diubah dalam bentuk teknologi.

Berdasarkan hasil penelitian dari Gresh (2015) yang menunjukkan bahwa model pembelajaran STSE berisikan pembelajaran mandiri. Pembelajaran mandiri dapat menghasilkan pembelajaran yang bermakna dalam menemukan konsep jika siswa mempunyai kreativitas yang tinggi. Pembelajaran dengan metode observasi laboratorium maupun metode observasi lapangan dan kreativitas siswa tidak mempengaruhi prestasi belajar secara bersama-sama meskipun jika secara terpisah berpengaruh. Siswa yang mempunyai kreativitas tinggi dengan metode observasi laporatorium maupun observasi lapangan akan dapat mencari keterkaitan antara unsur sains, teknologi, dan sosial sementara siswa yang mempunyai kreativitas rendah tidak dapat mencari keterkaitannya, sehingga menyebabkan hasil belajarpun untuk ketiga aspek tidak berpengaruh. Tidak adanya interaksi diantara keduanya bisa saja terjadi karena kelompok siswa yang terbentuk dalam pembelajaran tidak heterogen.

Tidak ada interaksi antara sikap ilmiah siswa, kreativitas siswa dengan terhadap prestasi belajar aspek kognitif, afektif dan psikomotor. Berdasarkan hasil pengujian hipotesis dua dapat dilihat pula adanya perbedaan prestasi belajar siswa dengan sikap ilmiah tinggi dan sikap ilmiah rendah, artinya sikap ilmiah berpengaruh terhadap prestasi belajar. Hasil pengujian hipotesis tiga, dapat dilihat adanya perbedaan prestasi belajar siswa dengan kreativitas tinggi dan kreativitas rendah. Hal ini menunjukkan bahwa kreativitas siswa berpengaruh terhadap prestasi belajar.

Sikap ilmiah dan kreativitas siswa, keduanya berpengaruh terhadap prestasi belajar siswa. Dapat diprediksi bahwa interaksi antara keduanya akan memberikan pengaruh yang berbeda terhadap prestasi belajar. Namun, realita yang terjadi adalah tidak terdapat interaksi antara keduanya, hal ini dapat dilihat dari hasil uji hipotesis. Keduanya hanya akan memberikan pengaruh terhadap prestasi belajar secara terpisah. Kombinasi keduanya tidak memberikan pengaruh terhadap prestasi belajar. Jika siswa memiliki kreativitas tinggi maka ia akan lebih untuk memecahkan permasalahan yang berkaitan dengan pengelolaan lingkungan.

Kondisi yang dijumpai adalah terdapat siswa meskipun memiliki kreativitas siswa tinggi, mengalami kesulitan dalam hal merangkai informasi yang diterima menjadi sebuah pengetahuan yang bermakna. Faktor yang menyebabkan kondisi tersebut adalah karena siswa memiliki sikap ilmiah yang rendah. Sebaliknya, dijumpai pula siswa dengan sikap ilmiah tinggi tetapi tidak serius dalam mengikuti proses pembelajaran, hal ini disebabkan karena siswa tersebut memiliki kreativitas rendah. Ketidakseriusan dalam pembejaran disebabkan karena jam pelajaran pada jam-jam akhir pembelajaran sehingga konsentrasi siswa manjadi terpengaruh.

Tidak ada interaksi antara model pembelajaran SETS dengan metode observasi laboratorium dan metode observasi lapangan, sikap ilmiah dan kreativitas siswa terhadap ketiga aspek prestasi belajar. Pembelajaran menggunakan model pembelajaran SETS dengan metode observasi laboratorium dan metode observasi lapangan, kreativitas siswa, dan sikap ilmiah tidak memberikan kontribusi secara bersama-sama terhadap prestasi belajar. Artinya pembelajaran 
menggunakan model SETS baik dengan metode observasi laboratorium maupun metode observasi lapangan, kreativitas siswa, dan sikap ilmiah akan memberikan efek terhadap prestasi belajar apabila secara terpisah. Model pembelajaran SETS merupakan paradigma baru dalam pembelajaran dan dalam tahap pelaksanaanya sumber daya manusia yang menyampaikan juga berpengaruh. Sejalan dengan hasil penelitian Pedretti (2006) bahwa pengajaran dengan STSE menumbuhkan kepercayaan dan motivasi dalam pengajaran yang menjadi kendala adalah konsistensi dalam praktek untuk beberapa materi.

Hasil penelitian menunjukkan bahwa siswa yang memiliki kreativitas tinggi apapun metodenya mempunyai prestasi belajar kognitif, afektif dan psikomotor yang tinggi dibandingkan siswa dengan kreativitas rendah. Tidak adanya interaksi antara pembelajaran menggunakan model pembelajaran SETS, kreativitas siswa dan sikap ilmiah ini mengacu pada hipotesis keempat bahwa tidak ada interaksi antara metode observasi laboratorium maupun metode observasi lapangan dan sikap ilmiah. Demikian juga pada hipotesis keenam yang menunjukkan tidak adanya interaksi antara sikap ilmiah dan kreativitas siswa. Kombinasi efek secara bersamasama antara ketiganya menjadi tidak terlihat. Siswa yang mempunyai kreativitas tinggi dan sikap ilmiah tinggi dengan model pembelajaran apapun tetap dapat beradaptasi, sehingga nilainya lebih tinggi dibandingkan siswa yang kreativitas dan sikap ilmiahnya rendah. Hubungan antara kategori sikap ilmiah dan kreativitas siswa, pada metode observasi laboratorium dan metode observasi lapangan terhadap prestasi belajar adalah sejajar.

Tidak adanya interaksi antara sikap ilmiah dan kreativitas siswa dapat dijelaskan antara lain pada tahap-tahap pembelajaran dirasa terlalu berat oleh siswa. Prestasi belajar tidak hanya dipengaruhi oleh variabel yang diteliti itu saja, tetapi juga dipegaruhi oleh variabel lain seperti intelegensi, motivasi, minat, bakat dan gaya belajar.

\section{Kesimpulan dan Rekomendasi}

Berdasarkan data yang telah dikumpulkan dan hasil analisis data yang telah dikemukakan maka dapat disimpulkan sebagai berikut:

1. Ada pengaruh prestasi belajar kognitif, afektif dan psikomotor antara siswa yang diberi model SETS dengan metode observasi laboratorium dan metode observasi lapangan.

2. Ada pengaruh sikap ilmiah tinggi dan sikap ilmiah rendah terhadap prestasi belajar kognitif, afektif dan psikomotorik.

3. Ada pengaruh antara kreativitas tinggi dan kreativitas rendah terhadap prestasi belajar kognitif, afektif dan psikomotorik.

4. Tidak ada interaksi prestasi belajar kognitif, afektif dan psikomotor antara siswa yang diberi pembelajaran biologi model SETS dengan metode observasi laboratorium dan metode observasi lapangan dengan sikap ilmiah siswa tinggi dan sikap ilmiah rendah.

5. Tidak ada interaksi prestasi belajar kognitif, afektif dan psikomotor antara siswa yang diberi pembelajaran biologi model SETS dengan metode observasi laboratorium dan metode observasi lapangan dengan kreativitas tinggi dan kreativitas rendah.

6. Tidak ada interaksi antara sikap ilmiah siswa, kreativitas siswa dengan terhadap prestasi belajar aspek kognitif, afektif dan psikomotor.

7. Tidak ada interaksi antara pembelajaran dengan model pembelajaran SETS dengan metode observasi laboratorium dan metode observasi lapangan, sikap ilmiah dan kreativitas siswa terhadap prestasi belajar aspek kognitif, afektif. 


\section{Daftar Pustaka}

Angel, Serrano-Aroca. (2015). Real and Virtual Bioreactor Laboratory Sessions by STSE-CLIL. Web Quest Journal.homepage: www.elsevier.com/locate/ece. Education for Chemical Engineers

Arsyad, A. (2005). Media Pembelajaran. Cetakan Keenam. Jakarta: Raja Grafindo Persada.

Baharuddin.(1982). Peranan Kemampuan Dasar Intelektual Sikap dan Pemahaman dalam Fisika Terhadap Kemampuan Siswa Di Sulawesi Selatan Membangun Model Mental. Disertasi Doktor FPS. IKIP Bandung

Binadja, A. (1999). Pendidikan SETS (Science, Enviroment, Technologi, and Society). Semarang: Universitas Negeri Semarang

Binadja, A. (2001). Wawasan SETS dalam Pengembangan Kurikulum Sains. Karya Tulis disajikan dalam Seminar Lokakarya Pendidikan SETS bekerja sama antara SAEMORESCAM, Penang, Malaysia dan UNNES

BNSP. (2007). Kurikulum Tingkat Satuan Pendidikan. Jakarta: Depdiknas

Budiningsih, A. (2005). Belajar dan Pembelajaran. Jakarta: Rineka Cipta

Brotowidjoyo, Mukayat D. (1985). Penulisan Karangan Ilmiah. Jakarta:Akademika Pressindo.

Budiyono, (2004). Statistika Untuk Penelitian ed. Ke-2, Surakarta; UNS Press.

Buzan, Tony. (2010). Buku Pintar Mind Map. Jakarta: Gamedia Pustaka.

Del Rosario, B.I. (2009). Science, Technology, Society and Environment (STSE) Approach in Environmental Science for Nonscience Students in a Local Culture. Vol. 6 No.1 December 2009.ISSN:2094-1064.CHED

Accedited Research Jurnal. Category B

Depdikbud. (1993). Kamus Besar Bahasa Indonesia. Jakarta: Balai Pustaka

Depdiknas. (2002). Kurikulum Berbasis Kompetensi. Kegiatan Belajar
Mengajar. Jakarta: Pusat Kurikulum Balitbang

Dewi, Shinta. (2008). Ketrampilan Proses Sains. Bandung: Tirta Emas

Figuerido, Rocha \& Dutra. (2016). CTSA Approach in Education: Opportunities and Challenges in Contuining Education Teachers. Article submitted in October/2015 and accepted in February/2016.DOI:10.15628/holos.20 16.3522

Gresh, H.(2015). Enhancing Decision-Making in STSE Education by Inducing Reflection and Self-Regulated Learning. Springer Science+Business Media Dordrecht.

Hakim, Thursan. (2001). Belajar dan Pembelajaran, Jakarta: Rineka Cipta.

Hawadi, Reni Akbar. (2001). Kreativitas. Jakarta: Grasindo

Herawati Susilo. (2000). Kapita Selekta Pembelajaran Biologi. Jakarta: Universitas Terbuka.

Hamalik, Ommar (1990). Psikologi Belajar Mengajar. Bandung: Sinar Baru

Margono. (2007). Metodologi Penelitian Pendidikan. Jakarta: Rineka Cipta

Maryati, S. (2009). Pembelajaran Sains, Teknologi Masyarakat dengan Metode Observasi Lingkungan Ditinjau dari Sikap Ilmiah dan Konsep Diri Siswa. Tesis: Program Studi Magister Pendidikan Sains FKIP Universitas Sebelas Maret Surakarta.

Masidjo. (1995). Penilaian Pencapaian Hasil Belajar Siswa di Sekolah. Yogjakarta.Kanisius

Munandar, Utami. (2004). Pengembangan Kreativitas Anak Berbakat. Jakarta: Rineka Cipta

Nuryani, Y. Rustaman. (2005). Strategi Belajar Mengajar Biologi-Cet. 1. Malang: Universitas Negeri Malang.

Panen, Paulina. (2004). Belajar dan Pembelajaran 1. Cetakan ke-6. Jakarta: Departemen Pendidikan Nasional.

Pedretti, EG. (2006). Promoting Issues-Based STSE Perspectives In Science Teacher 
Education: Problems Of Identtity and Ideology Sci \& Educ (2008) 17:941-960

Poedjiadi, A. (2005). Sains Teknologi Masyarakat. Bandung: Remaja Rosdakarya

Prayitno dan Erman Amri. (2004). Dasar-Dasar Bimbingan dan Konseling. Jakata: Rineka Cipta

Ratna Wilis Dahar. (1989). Teori-Teori Belajar. Jakarta. Erlangga

Riduwan. 2004. Belajar Mudah Penelitian Untuk Guru-Karyawan dan Peneliti Pemula. Alfabeta: Bandung.

Riyadi, S. (2009). Pembelajaran Ilmu Pengetahuan Alam Dengan Pendekatan Salingtemas Melalui Metode Eksperimen Dan Demontrasi Dengan Memperhatikan Kemampuan Awal Dan Kreativitas Siswa. Tesis: Program Studi Magister Pendidikan Sains FKIP Universitas Sebelas Maret Surakarta.

Sanjaya, Wina. (2008). Strategi Pembelajaran Berorientasi Standar Proses Pendidikan. Jakarta: Kencana Prenada Media Group.

Sardiman, A.M. (2001). Interaksi dan Motivasi Belajar Mengajar. Jakarta: Raja Grafindo

Sayekti, I.C. (2012). Pembelajaran IPA Menggunakan Pendekatan Inkuiri Terbimbing Melalui Metode Eksperimen Dan Demonstrasi Ditinjau Dari Kemampuan Analisis dan Sikap Ilmiah Siswa. jurnal.pasca.uns.ac.id. Vol 1. (2)

Setiyono, F.P. (2011). Pengembangan Perangkat Pembelajaran Kimia Kelarutan dan Hasil kali Kelarutan (KSP) Dengan Pendekatan SETS Untuk Meningkatkan Kemampuan Berpikir Kritis Dan Kreativitas Siswa. Journal Penelitian Pendidikan.Unnes.ac.id.Vol 1. (2)

Suharsimi Arikunto. (2006). Dasar-Dasar Evaluasi Pendidikan. Jakarta: Bumi Aksara

Slavin, Robert. (1994). Cooperative Learning: Theory, Reseach and Practice, London: Allymand Baca
Triandis, Harry.C. (1971). Attitude and Attitude Change. Toronto: Jhon Willey and Sons

Trowbridge and Bybee. (1991). Becoming a Secondary School Science Teacher. Colommbus: Merrill Publishing Company.

Ulum, B. (2007). Sikap Ilmiah.Diakses 25 Juli 2011, jam 23.53. Dari alamat website : http:

//www.blogbahrul.wordpress.com/200 7/11/28/ sikap-ilmiah/

Wasis, Sugeng Yuli Irianto. (2008). Ilmu Pengetahuan Alam I Untuk SMP dan MTs Kelas VII. Jakarta: Pusat Perbukuan Departemen Pendidikan Nasional.

Wartono. (2004). Materi Pelatihan Terintegrasi Sains. Jakarta: Depdiknas.

Wenno, I.H, (2008), Strategi Belajar Mengajar Sains Berbasis Kontekstual, Yogyakarta: Inti Media. 